\title{
Soypeptide lunasin in cytokine immunotherapy for lymphoma
}

\author{
Hua-Chen Chang $\cdot$ David Lewis $\cdot$ Chun-Yu Tung $\cdot$ Ling Han $\cdot$ Sarah M. P. Henriquez $\cdot$ Larry Voiles $\cdot$ \\ Ivan P. Lupov • David Pelloso • Anthony L. Sinn · Karen E. Pollok • Ben O. de Lumen · Fang Li • \\ Janice S. Blum • Shivani Srivastava $\cdot$ Michael J. Robertson
}

Received: 25 March 2013 / Accepted: 12 December 2013 / Published online: 22 December 2013

(c) The Author(s) 2013. This article is published with open access at Springerlink.com

\begin{abstract}
Immunostimulatory cytokines can enhance anti-tumor immunity and are part of the therapeutic armamentarium for cancer treatment. We have previously reported that post-transplant lymphoma patients have an acquired deficiency of signal transducer and activator of transcription 4, which results in defective IFN $\gamma$ production during clinical immunotherapy. With the goal of further improving cytokine-based immunotherapy, we examined the effects of a soybean peptide called lunasin that synergistically works with cytokines on natural killer (NK) cells. Peripheral blood mononuclear cells of healthy donors and post-transplant lymphoma patients were stimulated with or without lunasin in the presence of IL-12 or IL-2. NK activation was evaluated, and its tumoricidal activity was assessed using in vitro and in vivo tumor models. Chromatin immunoprecipitation assay was performed to evaluate the histone modification of gene loci that are regulated by lunasin and cytokine. Adding lunasin to IL-12- or
\end{abstract}

H.-C. Chang $(\bowtie) \cdot$ D. Lewis $\cdot$ C.-Y. Tung $\cdot$ L. Han •

S. M. P. Henriquez $\cdot$ L. Voiles $\cdot$ I. P. Lupov

Department of Biology, School of Science,

Indiana University-Purdue University Indianapolis,

723 West Michigan Street, SL310, Indianapolis, IN 46202, USA

e-mail: huchang@iupui.edu

D. Pelloso $\cdot$ S. Srivastava $\cdot$ M. J. Robertson $(\square)$

Bone Marrow and Stem Cell Transplantation Program,

Lymphoma Program, Division of Hematology/Oncology,

Department of Medicine, Indiana University School of Medicine,

535 Barnhill Dr., Room 473, Indianapolis, IN 46202, USA

e-mail:mjrobert@iupui.edu

\section{A. L. Sinn · K. E. Pollok}

In Vivo Therapeutics Core, HB Wells Center for Pediatric

Research, Departments of Pediatrics and Pharmacology

and Toxicology, Indiana University Simon Cancer Center,

Indianapolis, IN, USA
IL-2-stimulated NK cells demonstrated synergistic effects in the induction of IFNG and GZMB involved in cytotoxicity. The combination of lunasin and cytokines (IL-12 plus IL-2) was capable of restoring IFN $\gamma$ production by NK cells from post-transplant lymphoma patients. In addition, NK cells stimulated with lunasin plus cytokines displayed higher tumoricidal activity than those stimulated with cytokines alone using in vitro and in vivo tumor models. The underlying mechanism responsible for the effects of lunasin on NK cells is likely due to epigenetic modulation on target gene loci. Lunasin represents a different class of immune modulating agent that may augment the therapeutic responses mediated by cytokine-based immunotherapy.

Keywords Lunasin - NK · Cytokine immunotherapy · Lymphoma

B. O. de Lumen

Nutritional Sciences and Toxicology, UC Berkeley,

Berkeley, CA, USA

F. Li

Department of Mathematical Sciences, School of Science, Indiana University-Purdue University Indianapolis, Indianapolis, IN, USA

J. S. Blum

Department of Microbiology and Immunology, Indiana University School of Medicine, Indianapolis, IN, USA 


\section{Introduction}

Cytokine immunotherapy is one of the therapeutic strategies to harness the power of immunosurveillance to eradicate cancer cells. Numerous cytokines have been used in clinical trials to enhance anti-tumor immunity [1]. Among these cytokines, IFN $\gamma$ has been recognized as its pivotal role in anti-tumor immunity by enhancing tumor immunogenicity for antigen presentation $[2,3]$, inducing apoptosis in tumor cells [4], promoting $\mathrm{T}$ helper 1 (Th1) differentiation $[5,6]$ and augmenting cytotoxicity of CD8+ cytotoxic $\mathrm{T}$ lymphocytes (CTLs) [7]. However, administration of recombinant IFN $\gamma$ had disappointing outcomes in various cancer immunotherapy trials possibly due to its toxicity [8]. Efforts have focused on induction of endogenous IFN $\gamma$ by natural killer (NK) or $\mathrm{T}$ cells following stimulation with cytokines IL-2, IL-12, IL-15, IL-18, and IL-21, which have been used individually or in different combinations [9-13]. The successful production of IFN $\gamma$ is required for the efficacy of several immunotherapeutic approaches including IL-12 immunotherapy [14-16].

IL-12 can be given in biologically active doses to patients with lymphoma after high-dose chemotherapy followed by autologous peripheral blood stem cell transplantation (PBSCT) [17, 18]. However, these heavily treated patients have acquired deficiency of signal transducer and activator of transcription 4 (STAT4), which contributes to impaired production of IFN $\gamma$ following IL-12 immunotherapy [19, 20]. We subsequently defined the mechanism in which acquired STAT4 deficiency in T and NK populations is caused by the chemotherapeutic regimen [21]. Failure of patient $\mathrm{T}$ or NK cells to adequately produce IFN $\gamma$ would likely compromise the therapeutic effects during cytokine immunotherapy. The goal of this study was to develop an efficacious immune therapy that would enhance anti-tumor activity for chemotherapytreated lymphoma patients who acquire immune dysfunctions.

In this study, we have identified a new use for the soypeptide lunasin as an immune modulating agent that synergistically works with therapeutic cytokines to enhance NK-mediated anti-tumor activity. Lunasin is a seed peptide containing 43 amino acids [22], known for its chemopreventive properties capable of suppressing tumor growth [23]. Our results have demonstrated that lunasin in combination with IL-12 or IL-2 exerts a robust synergistic effect on increasing IFN $\gamma$ and granzyme B expression by NK cells; and this synergism leads to strong NK activation with enhanced cytotoxicity. Notably, the combination of luna$\sin$ and cytokines is capable of rescuing IFN $\gamma$ production by NK cells from heavily treated lymphoma patients who are immune compromised. Our results suggest promise for lunasin in complementing existing modalities with IL-12 or IL-2 to improve therapeutic responses of cytokine-based cancer immunotherapy.

\section{Materials and methods}

Cytokines, antibodies, and lunasin peptides

Recombinant human IL-2 was obtained from Prometheus Laboratories (San Diego, CA) and recombinant human IL-12 from PeproTech (Rocky Hill, NJ). Fluorochromeconjugated monoclonal antibodies to human $\mathrm{CD} 3, \mathrm{CD} 4$, CD8, CD14, CD56, FasL (CD178), IFN $\gamma$, mouse CD3, CD69, NKp46, and human/mouse granzyme B were obtained from BD Biosciences (San Jose, CA). FicollPaque $^{\mathrm{TM}}$ PLUS was purchased from GE Healthcare BioSciences (Piscataway, NJ). The lunasin peptide with 43 amino acids was chemically synthesized with $97 \%$ purity by LifeTein (South Plainfield, NJ), which include the following sequences: SKWQHQQDSCRKQLQGVNLTPCEKHIMEKIQGRGDDDDDDDDD. A truncated peptide (32 amino acids) lacking the RGD motif and the poly-D tail was synthesized by LifeTein. A negative control peptide with scrambled sequences (RKMELQEGI HLKKGDQNTQSQSCQPKC IQVWH) that maintains the same molecular weight to the truncated peptide was synthesized. An additional negative control peptide containing an epitope from the influenza matrix protein $\left(\mathrm{M}_{58-66}\right)$ which binds to human MHC class I molecules was also synthesized. All the peptides were dissolved in sterilized water at stock concentration of $5 \mathrm{mM}$.

\section{Human blood samples and primary cell cultures}

Collection of blood was approved by the Institutional Review Board at Indiana University Medical Center, and written informed consent was obtained from each study subject. Blood samples were obtained from patients with lymphoma after treatment with high-dose chemotherapy and PBSCT. Healthy human blood samples were procured from the Indiana Blood Center (Indianapolis, IN). Peripheral blood mononuclear cells (PBMCs) were isolated using Ficoll-Paque ${ }^{\mathrm{TM}}$ PLUS, and aliquots of PBMCs were cryopreserved in liquid nitrogen. Human NK cells were isolated from normal control PBMCs using positive or negative selection kits (Miltenyi Biotech, Auburn, CA). Human B lymphoma cell line Raji cell line was obtained from American Type Culture Collection (ATCC, Manassas, VA, USA).

\section{Evaluation of IFN $\gamma$ production}

IFN $\gamma$ production at the single-cell levels was evaluated using intracellular cytokine staining from PBMCs following stimulation as indicated [24]. Secreted IFN $\gamma$ protein collected from the supernatant or mouse serum was measured using ELISA [19, 20]. 
Analysis of gene expression

Purified human NK cells were stimulated as indicated. One day following stimulation, the cell pellets were subjected to analysis of gene expression using real-time qPCR with Taqman assay primers for $I F N G, C S F 2$, GZMB, TGFB1, and TGFBR2.

The half-maximal effective concentration $\left(\mathrm{EC}_{50}\right)$ of lunasin

The $\mathrm{EC}_{50}$ of lunasin was calculated from the doseresponse curve in IFN $\gamma$ production using Origin Program (OriginLab, Northampton, MA). The $\mathrm{EC}_{50}$ is presented as mean \pm SD averaged from four different normal controls.

In vitro cytotoxicity assays

Purified human NK cells stimulated as indicated for 1 day were washed and co-cultured with target cells (Raji) at the ratio of $10: 1$ for $4 \mathrm{~h}$ at $37{ }^{\circ} \mathrm{C}$ in a $5 \% \mathrm{CO}_{2}$ incubator. NK-mediated lysis was analyzed using the CytoTox 96 Non-Radioactive Cytotoxicity Assay Kit (Promega, Madison, WI). For some assays, NK cells were incubated with anti-FasL-blocking antibody (NOK-1 clone, BioLegend) or the isotype control (IgG1) at $10 \mu \mathrm{g} / \mathrm{ml}$ for $2 \mathrm{~h}$ [25] followed by co-culturing with Fas-expressing target cells (Raji).

Adoptive transfer of human NK cells in xenograft model in vivo

$\mathrm{NOD} / \mathrm{SCID} / \mathrm{gc}^{\text {null }}$ (NSG) mice (The Jackson Laboratory, Bar Harbor, Maine) at 2 months old were injected subcutaneously on day 1 with $0.5 \times 10^{6}$ Raji cells in $0.1 \mathrm{ml}$ PBS mixed with $0.1 \mathrm{ml}$ Matrigel (BD Biosciences, San Jose, CA). Human NK cells isolated from healthy control donors were stimulated as indicated for 1 day. On day 2, these pretreated NK cells were washed and injected into the tumor site $\left(2.5 \times 10^{6} /\right.$ mouse $)$. Tumor growth was monitored, and the volumes were measured using standard manual calipers.

NK activation in mice following short-term and long-term treatment

BALB/c mice received short-term (daily single IP injection for 3 consecutive days) or long-term (daily single IP injection for 5 consecutive days per week for a total of 8 weeks) treatment with PBS $(-)$, IL-2 $\left(1 \times 10^{5} \mathrm{U} /\right.$ mouse $)$ without $(-)$ or with $(+)$ lunasin $(0.4 \mathrm{mg} / \mathrm{kg}$ body weight $)$, or lunasin alone. Blood samples were collected by cardiac puncture, and serum levels of IFN $\gamma$ were determined using ELISA. NK activation was analyzed from spleens in these mice using staining antibodies for surface activation marker
CD69 and intracellular granzyme B. IFN $\gamma$ production by NK cells was evaluated using intracellular staining from splenocytes that were incubated with GolgiPlug (Brefeldin A) for $4 \mathrm{~h}$ at $37{ }^{\circ} \mathrm{C}$ in a $5 \% \mathrm{CO}_{2}$ incubator followed by flow cytometry analysis.

\section{Chromatin immunoprecipitation (ChIP)}

The ChIP experiment was performed using isolated human NK cells treated 1 day as indicated following the established protocol [26, 27]. Antibodies against acetyl-histone $\mathrm{H} 3$ (AcH3), histone H3 trimethyl Lys9 (H3K9me3), and non-immune rabbit serum were obtained from Millipore (Billerica, MA).

Analysis of STAT4 activation by Western blot

Purified human NK cells were stimulated for $22 \mathrm{~h}$. Western blot analysis was performed from total protein extracts of cultured NK cells to measure the activation of STAT4 using an anti-phospho-STAT4 (Y693) antibody (Cell Signaling Technology, Danvers, MA). The same blot was reprobed with an anti-STAT4 monoclonal antibody (BD Biosciences, San Jose, CA) for the total amount of STAT4.

Statistical analysis

SAS/STAT (SAS Institute Inc., Cary, NC) was used to analyze the data. A mixed model was developed for analyzing the data with within-subject treatments, and the pairwise comparisons among the treatments were performed to determine the $P$ values. Statistical significance between groups of mice was determined using an independent sample Student's $t$ test.

\section{Results}

Lunasin stimulates human NK cells to produce IFN $\gamma$

To determine whether lunasin can induce cellular IFN $\gamma$ production, PBMCs from healthy donors were stimulated with or without lunasin in the presence or absence of IL-12 or IL-2. Because IL-12 and IL-2 are known to induce the production of IFN $\gamma$ by NK cells [1], these two cytokines were included in the stimulation for comparison. Following 1 day of stimulation, distinct cell populations that responded to stimulation were evaluated using intracellular staining for IFN $\gamma$. We found that CD4+ and CD8+ $\mathrm{T}$ populations remained negative with all stimuli (data not shown), while NK cells gated on CD3- CD56+ populations (Fig. 1a) had increased IFN $\gamma$ positive cells following stimulation with lunasin and IL-12 or IL-2 compared 
(A) (B)

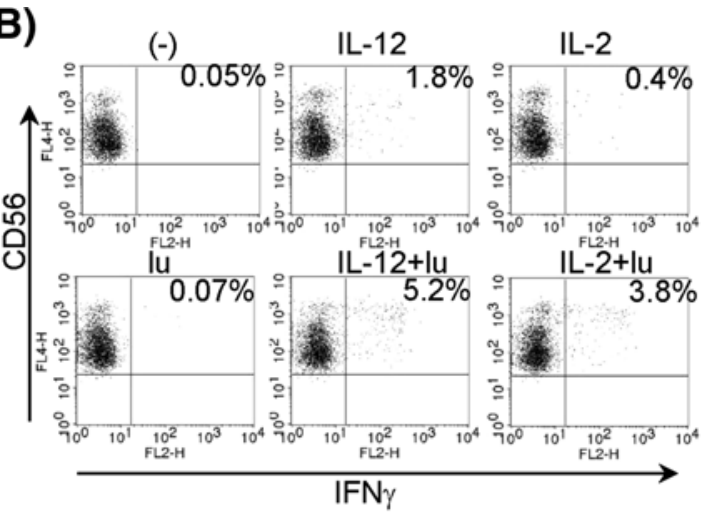

(C)

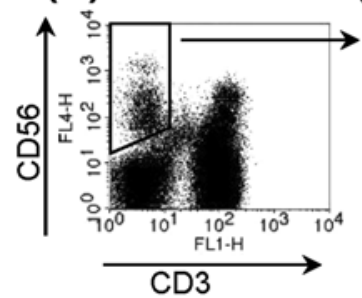

(E)

(D)

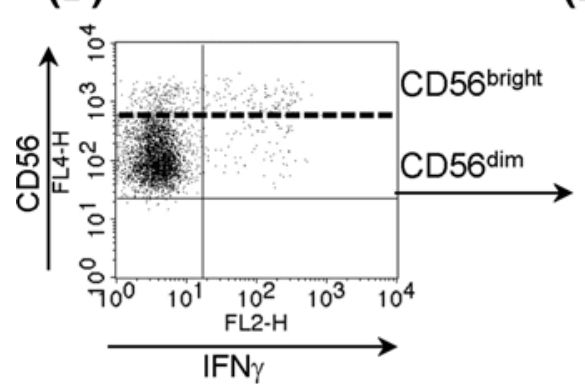

(F)

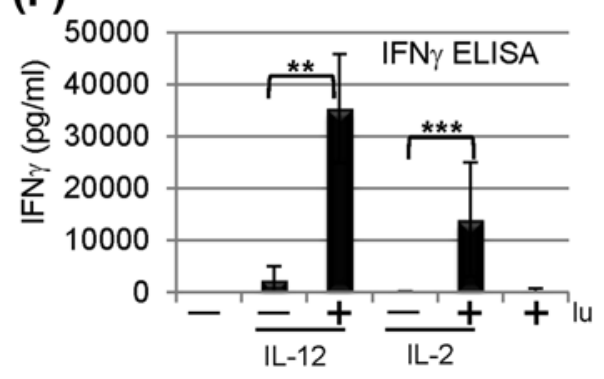

(H)

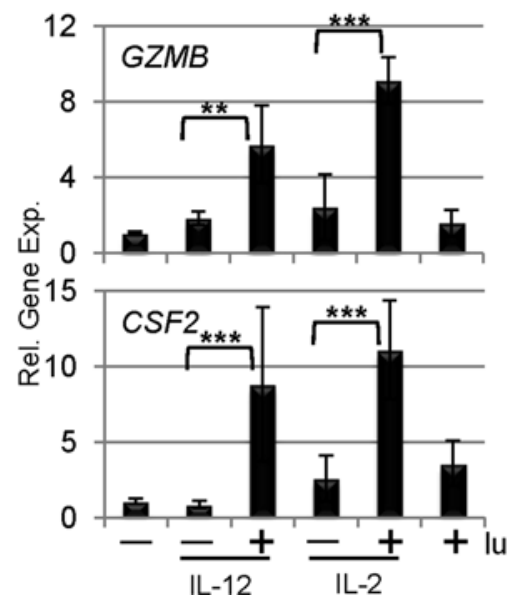

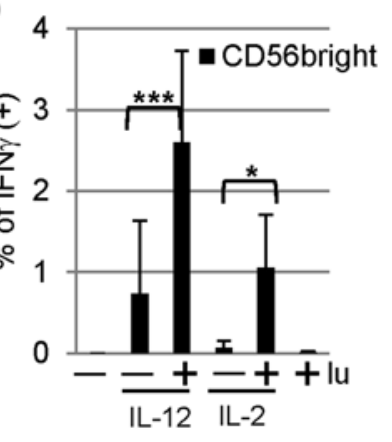

(G)

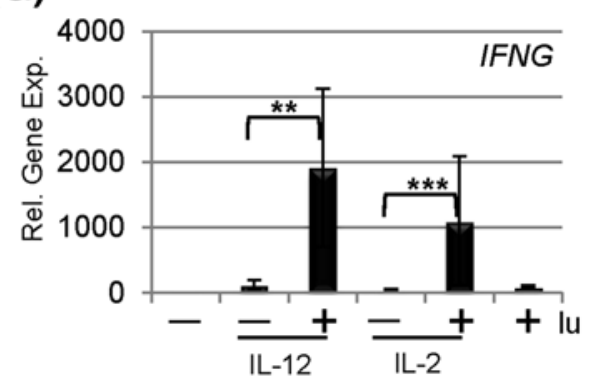

(I)

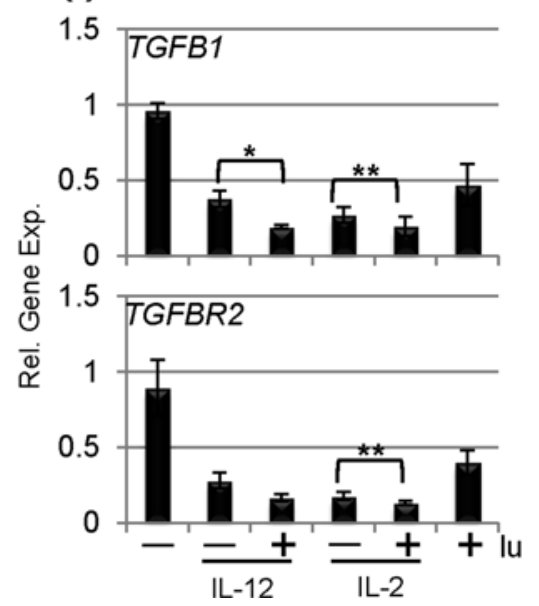

with cytokine alone (Fig. 1b, c). CD56 bright subsets of NK cells are major IFN $\gamma$ producers with regulatory functions, while CD56 dim populations exert cytolytic activity $[28,29]$. We also analyzed intracellular IFN $\gamma$ production
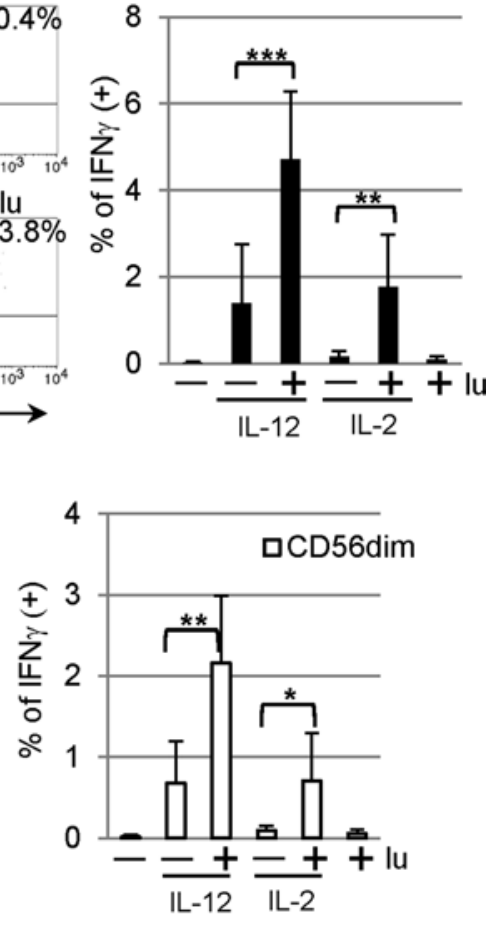
\Fig. 1 Lunasin stimulates human peripheral NK cells. Peripheral blood mononuclear cells (PBMCs) of normal controls were stimulated with medium only (-), lunasin at $20 \mu \mathrm{M}$ (lu), cytokine IL-12 at $10 \mathrm{ng} / \mathrm{ml}$ or IL-2 at $100 \mathrm{U} / \mathrm{ml}$, and cytokine plus lunasin for $24 \mathrm{~h}$. The lunasin peptide was chemically synthesized by LifeTein (South Plainfield, NJ). The production of IFN $\gamma$ at single-cell levels was analyzed using intracellular cytokine staining $(\mathbf{a}-\mathbf{e})$. At the last $6 \mathrm{~h}$ of stimulation, golgistop (monensin) was added to block the secretion of IFN $\gamma$. Stimulated PBMCs were surface stained with FITC-conjugated CD3 and APC-conjugated CD56 monoclonal antibodies, washed, fixed, and permeabilized. After washing, cells were incubated with PE-conjugated anti-IFN $\gamma$ monoclonal antibody. Expression of IFN $\gamma$ was evaluated using flow cytometry on 5,000 events of gated CD3 negative and CD56 positive NK cell populations (a). A representative dot plot from one donor shows the percentage of IFN $\gamma$ producing NK populations following various treatments (b), and the averaged percentage of IFN $\gamma$ producing $\mathrm{NK}$ populations are presented as mean \pm SD from 5 different normal donors (c). IFN $\gamma$ producing $\mathrm{NK}$ cells are further segregated into CD56 bright and CD56 dim populations (d), and the percentage of IFN $\gamma$ producing CD56 bright or CD56 dim populations is averaged from the same 5 donors as in $\mathbf{c}$ and presented as mean $\pm \mathrm{SD}(\mathbf{e})$. $\mathbf{f}$ The secretion of IFN $\gamma$ by purified NK cells following stimulation was analyzed using ELISA. Freshly isolated human NK cells from PBMCs of normal controls using positive selection with CD56 magnetic beads (Miltenyi Biotec, Auburn, $\mathrm{CA})$ were stimulated as in $\mathbf{b}$. Following 1 day of stimulation, cell-free supernatants were evaluated for IFN $\gamma$ production, and data are presented as mean \pm SD averaged from 5 different controls. $\mathbf{g}-\mathbf{i}$ Effects of lunasin on gene expression by human NK cells. The cell pellets collected from $\mathbf{f}$ were resuspended in Trizol Reagents for total RNA extraction. The first-strand cDNA was synthesized followed by realtime qPCR using Taqman assay with primers for $\mathbf{g}$ IFN $\gamma($ IFNG), $\mathbf{h}$ granzyme $\mathrm{B}(G Z M B)$ and granulocyte-macrophage colony-stimulating factor (GM-CSF or CSF2), and i TGF $\beta$ (TGFB1) and TGF $\beta$ receptor (TGFBR2) in ABI 7300 (Applied Biosystems by Life Technologies, Carlsbad, CA). Data are presented as mean \pm SD averaged from 5 different controls. $* P \leq 0.05$; $* * P \leq 0.01$; *** $P \leq 0.001$

was further confirmed by stimulation of purified human NK cells using either positive selection (purity ranging from 80 to $92 \%$ ) or negative selection (purity $97 \%$ ). Results showed that exposure of lunasin in combination with IL-12 or IL-2 markedly increased the levels of IFN $\gamma$ secreted by purified NK cells irrespective of the method of purification (Fig. 1f). The mRNA expression of IFNG from the cell pellets of the same cultures correlated with the ELISA results (Fig. 1g). Consistent with intracellular staining, purified $\mathrm{CD} 4+$ or $\mathrm{CD} 8+\mathrm{T}$ cells produced undetectable levels of IFN $\gamma$ under the same stimulation conditions (data not shown). Thus, exposure of NK cells to lunasin amplifies the responsiveness of these cells to IL-12 or IL-2 as measured by IFN $\gamma$ production.

\section{Lunasin regulates gene expression by NK cells}

Because of robust synergistic effects of lunasin with IL-12 or IL-2 on inducing IFNG expression, we next evaluated whether lunasin was able to modulate other target genes that are regulated by IL-12 or IL-2. Results of qPCR from samples in Fig. 1g showed that adding lunasin to IL-12 or
IL-2 significantly increased expression of GZMB (granzyme B) and CSF2 (granulocyte-macrophage colonystimulating factor or GM-CSF) as compared to treatment with cytokine alone (Fig. 1h). Cytokine IL-12 or IL-2 stimulation is known to downregulate TGFB1 and TGFBR2 expression by NK cells [30], and adding lunasin to cytokine-treated NK cultures resulted in further reduction of TGFB1 and TGFBR2 expression as compared to treatment with cytokines alone (Fig. 1i). Thus, it appeared that lunasin exerted synergistic effects imposed by the selected cytokine IL-12 or IL-2 on modulating expression of target genes in NK cells.

Dose-dependent effects of lunasin in combination with cytokines

To define the dose response of lunasin in combination with cytokines, we determined the $\mathrm{EC}_{50}$ based on the IFN $\gamma$ production by IL-12-cultured human NK cells. At IL-12 concentration of $10 \mathrm{ng} / \mathrm{ml}$, the $\mathrm{EC}_{50}$ for lunasin was $5.64 \pm 2.23 \mu \mathrm{M}(n=4)$ (Fig. 2a). To determine whether lunasin could amplify the synergistic induction by cytokine cocktails with IL-2 and IL-12, human NK cells were cultured in both cytokines without or with lunasin. Based on the $\mathrm{EC}_{50}$ of lunasin, we chose its concentrations of 5 , 20 , and $80 \mu \mathrm{M}$. We found that lunasin also synergistically worked with cytokine cocktails on IFN $\gamma$ production (Fig. 2b).

Rescuing IFN $\gamma$ production by NK cells from lymphoma patients post-transplant

As reported previously, STAT4 deficiency was observed in lymphoma patients after PBSCT [21]. Stimulation of patient PBMCs with both IL-12 and IL-2 resulted in production of IFN $\gamma$ by $\mathrm{NK}$ populations using intracellular staining (Fig. 3a), albeit at a much lower percentage as compared to cells from normal controls (Fig. 3b). However, adding lunasin to the stimulation further increased the percentage of patient NK cells that produced IFN $\gamma$, which was similar to the level from normal controls stimulated with both cytokines $(P=0.446)$ (Fig. $3 b)$. Thus, incorporating lunasin into cytokine-based treatment may rescue the production of IFN $\gamma$ by NK cells from heavily treated lymphoma patients with acquired STAT4 deficiency.

Lunasin augments cytotoxicity by cytokine-activated NK cells

NK cells cultured in medium exhibited poor cytolytic activity against Raji lymphoma cells that are resistant to NK-mediated killing (Fig. 4a). Cytokine treatment led to NK activation, which enhanced the cytotoxicity against 

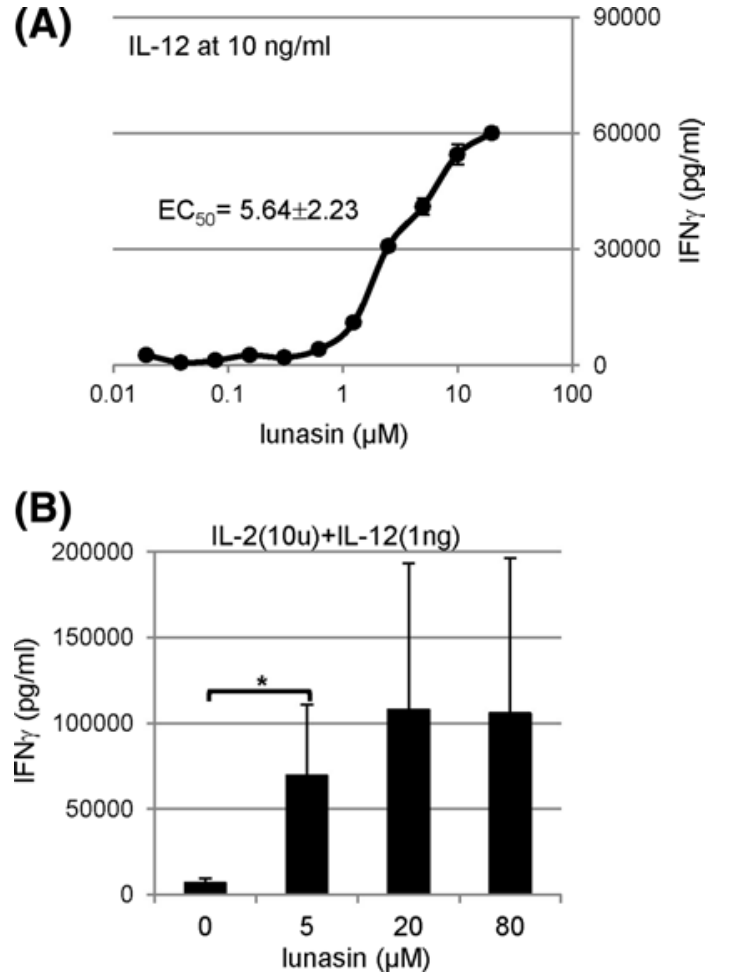

Fig. 2 Dose-dependent effects of lunasin in combination with cytokines. Freshly isolated human NK cells from PBMCs of normal controls (described in Fig. 1f) were stimulated as indicated, and the production of IFN $\gamma$ in the supernatants was determined using ELISA following one day of stimulation. a The half-maximal effective concentration $\left(\mathrm{EC}_{50}\right)$ of lunasin was calculated from the dose-response curve in IFN $\gamma$ production by NK cultured with IL-12 at $10 \mathrm{ng} / \mathrm{ml}$ using Origin Program (OriginLab, Northampton, MA). One representative curve based on the dose response in IFN $\gamma$ production is shown. The $\mathrm{EC}_{50}$ is presented as mean $\pm \mathrm{SD}$ averaged from 4 different normal controls. b Isolated NK cells as described in a were stimulated with both cytokines (IL-2 at $10 \mathrm{U} / \mathrm{ml}$ and IL-12 at $1 \mathrm{ng} / \mathrm{ml}$ ) in the combination with lunasin at different concentrations ranging from 5,20 , and $80 \mu \mathrm{M}$. One day following stimulation, the production of IFN $\gamma$ in the supernatants was determined using ELISA. Data are presented as mean \pm SD averaged from 3 different normal controls. $* P \leq 0.05$

Raji cells (Fig. 4a). Moreover, lunasin further augmented the natural cytotoxicity of NK cells that were negatively selected (97\% purity) and stimulated with suboptimum concentrations of cytokines against Raji cells (Fig. 4a).

Granzyme B is constitutively expressed by human periphery NK cells, and its level is associated with the lytic activity. IL-2 appeared to induce a higher GZMB by total NK cells as compared to IL-12 (Fig. 1h, upper panel). We next analyzed the effects of suboptimum IL-2 with or without lunasin on the expression of granzyme B using intracellular staining. In concert with the gene expression result, lunasin increased the protein levels of granzyme B in total NK cells cultured in IL-2 (MFI $140 \pm 99$ for IL-2-treated vs. $163 \pm 104$ for $\mathrm{IL}-2+$ lunasin-treated NK; mean $\pm \mathrm{SD}$ averaged from 3

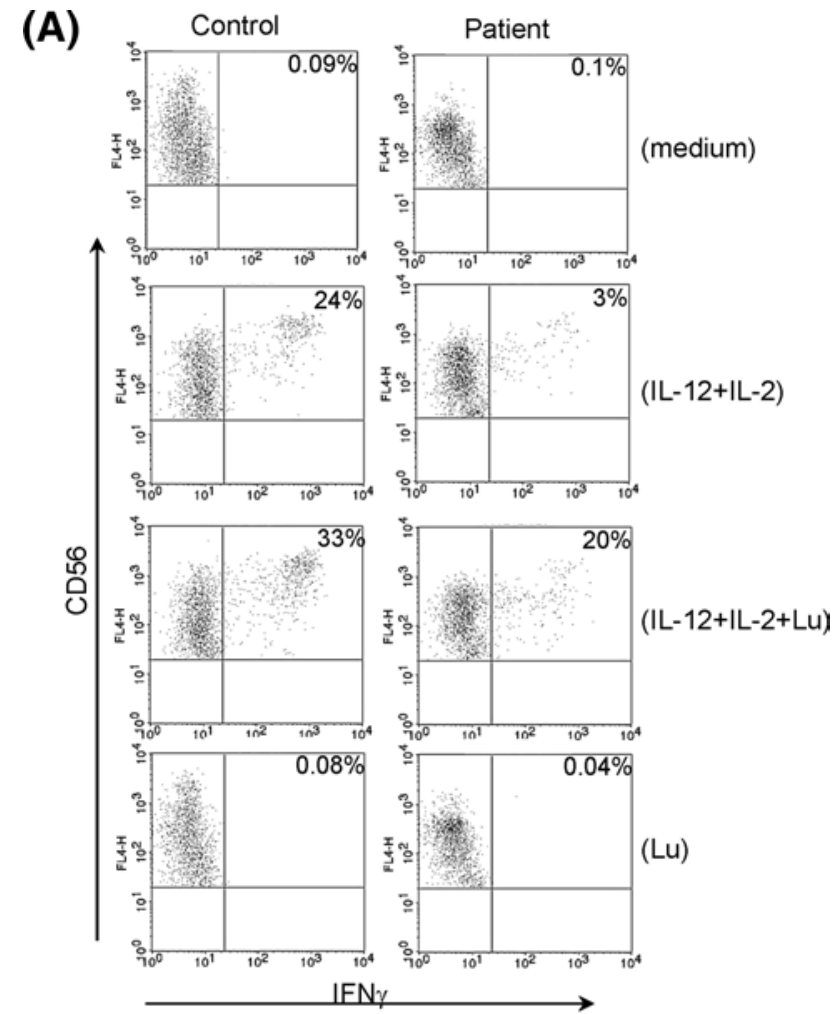

(B)

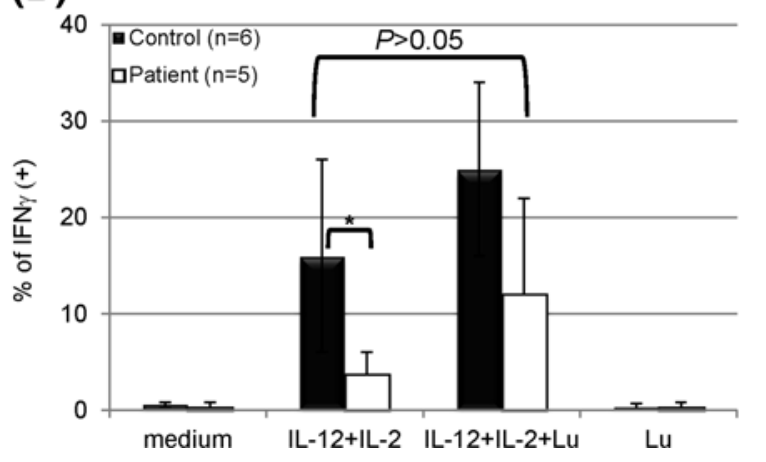

Fig. 3 Rescuing IFN $\gamma$ production by NK cells from lymphoma patients post-transplant. PBMCs of normal controls and post-transplant lymphoma patients were stimulated with medium only (-), IL-12 $(10 \mathrm{ng} / \mathrm{ml})$ and IL-2 (100 U/ml), IL-12 and IL-2 plus lunasin (lu, $20 \mu \mathrm{M}$ ), or lunasin alone for 1 day. The production of IFN $\gamma$ at single-cell levels was analyzed using intracellular cytokine staining as described in Fig. 1a, and a representative dot plot from one control and patient is shown in a. The percentage of IFN $\gamma$ positive NK populations (CD3 negative and CD56 positive) are presented as mean \pm SD averaged from 6 normal controls and 5 patients (1 patient at 6-12 month and 4 patients at 3-6 months post-transplant) (b). $* P \leq 0.05$

controls). We also found that both CD56 bright and dim populations had a higher granzyme B when lunasin was included in the culture as compared to IL-2 only (Fig. 4b).

To investigate whether lunasin could affect the FasLinduced apoptosis by IL-2-cultured NK cells, we first evaluated the surface expression of FasL following 1 day 
stimulation. Flow cytometry analysis showed minimum effects of lunasin on surface expression of FasL in NK cells cultured in suboptimum IL-2 $(3 \pm 1.2 \%$ of FasL + NK in IL-2-treated vs. $2.7 \pm 0.8 \%$ in IL-2+ lunasin-treated, $n=2$ ). In addition, cultured NK cells treated with FasLblocking antibody or the isotype control had similar killing activity against Fas-expressing Raji target cells (Fig. 4c), suggesting that lunasin had no effect on FasL-mediated killing by NK cells activated with suboptimum IL-2.

Cellular therapy using NK cells activated in vitro has been tested clinically against several tumors [31-33]. In a Raji lymphoma xenograft model, tumor growth increased over time in the control mice without transferred human NK cells (Fig. 4d). While tumor growth was attenuated at day 27 in mice receiving cytokine-activated NK cells, the group receiving NK cells activated with lunasin and cytokine had lowest tumor size when compared with the control group without transferred human NK cells (Fig. 4d).

\section{In vivo effect of lunasin on serum IFN $\gamma$ secretion}

To assess whether lunasin could enhance IFN $\gamma$ production in vivo, BALB/c mice were given single IP injection with IL-2 in the presence and absence of lunasin as indicated. Eighteen hours following the treatment, we were unable to detect serum IFN $\gamma$ levels from mice receiving PBS, IL-2, or lunasin. In contrast, the combination of IL-2 and lunasin resulted in the secretion of IFN $\gamma$ in the serum using lunasin at the dose at $0.4 \mathrm{mg} / \mathrm{kg}$ body weight (Fig. 5a).

NK activation in vivo following short-term treatment

The effects of lunasin in vivo on NK activation were examined. Given the toxicity-related death caused by cytokine storm with high levels of IFN $\gamma$ [34], we thus chose the regimen of IL-2 at suboptimal dose in order to keep animal alive for analysis. We analyzed NK cells gated on CD3-NKp46+ populations (Fig. 5b) from spleens of mice receiving short-term treatment (daily single IP injection for 3 days). The combination of lunasin and IL-2 resulted in significant increase in the percentage of CD69+ or granzyme B + NK cells as compared to those treated with PBS (Fig. 5C, upper and middle panels). Intracellular staining identified NK cells to be responsible for IFN $\gamma$ production in mice treated with both lunasin and IL-2 (Fig. 5c, lower panel). While IL-2 at suboptimal dose had undetectable effects in this short-term treatment, adding lunasin to IL-2 was able to induce NK activation.

NK activation in vivo following long-term treatment

Following long-term treatment (daily single IP injection for 5 days per week with a total of 8 weeks), these mice exhibited similar percentage of NK cells (CD3-NKp46+) and spleen cellularity (data not shown). Long-term treatment with IL-2 in this setting resulted in NK activation (evidenced by increased expression of CD69, granzyme B, and IFN $\gamma$; Fig. 5d) as well as increased levels of serum IFN $\gamma$ (Fig. 5e). In the presence of lunasin, however, the in vivo effects of IL-2 on NK activation and serum IFN $\gamma$ production were compromised (Fig. 5d, e).

Mechanisms of synergistic effects mediated by lunasin

Lunasin peptide contains a RGD motif that is involved in the binding of integrins that are expressed on various cell types including NK cells [35]. To directly study the function of RGD motif in lunasin, a truncated peptide lacking the RGD motif and the poly-D tail, a negative control peptide containing scrambled amino acids, and an influenzaderived peptide that binds to MHC class I molecules, were chemically synthesized. This truncated peptide induced similar levels of IFN $\gamma$ in NK cells compared with that using the full-length lunasin (Fig. 6a), suggesting the last 11 amino acids are not required for lunasin's immune modulatory function in NK cells although they are critical for inducing apoptosis in transformed cancer cells [36]. In addition, the scrambled negative control peptide as well as influenza-derived peptide did not induce detectable levels of IFN $\gamma$ (Fig. 6a, and data not shown), which ruled out the non-specific effects at the concentrations used $(20 \mu \mathrm{M})$.

It has been shown that lunasin is capable of inhibiting the acetylation of histone $\mathrm{H} 3$ by $\mathrm{p} 300 / \mathrm{CBP}$-associated factor (PCAF), a histone acetylase enzyme [23]. Epigenetic regulation by chromatin modification is known to alter gene expression [37]. The effects of lunasin on epigenetic regulation of NK cells were examined. Consistent with gene expression profiles of TGFB1 (Fig. 1i, upper panel), the level of acetylated histone $\mathrm{H} 3(\mathrm{AcH} 3)$ was negatively associated with TGFBI locus, and less DNA was pulled down by the anti-AcH3 antibody in NK cells treated with lunasin and IL-12 as compared to that with IL-12 alone (Fig. 6b, lower panel). Conversely, the level of $\mathrm{AcH} 3$ was positively associated with $I F N G$ locus to a greater degree in NK cells treated with lunasin plus IL-12 than that treated with cytokine alone (Fig. 6b, upper panel). Results suggest the ability of lunasin for modulating the levels of $\mathrm{AcH} 3$ bound to the target genes, resulting in gene regulation.

Histone mark with tri-methylated histone $\mathrm{H} 3$ at lysine 9 (H3K9me3) is associated with transcriptional repression [38]. We next tested whether changes in the repressive epigenetic marker $\mathrm{H} 3 \mathrm{~K} 9 \mathrm{me} 3$ were also associated with IL-12-mediated gene regulation in NK cells. Results in Fig. 6c showed a very limited binding of $\mathrm{H} 3 \mathrm{~K} 9 \mathrm{me} 3$ in the gene loci including $T G F B I$ and $I F N G$, suggesting that $\mathrm{H} 3 \mathrm{~K} 9 \mathrm{me} 3$ was not involved in IL-12-mediated gene 
(A)
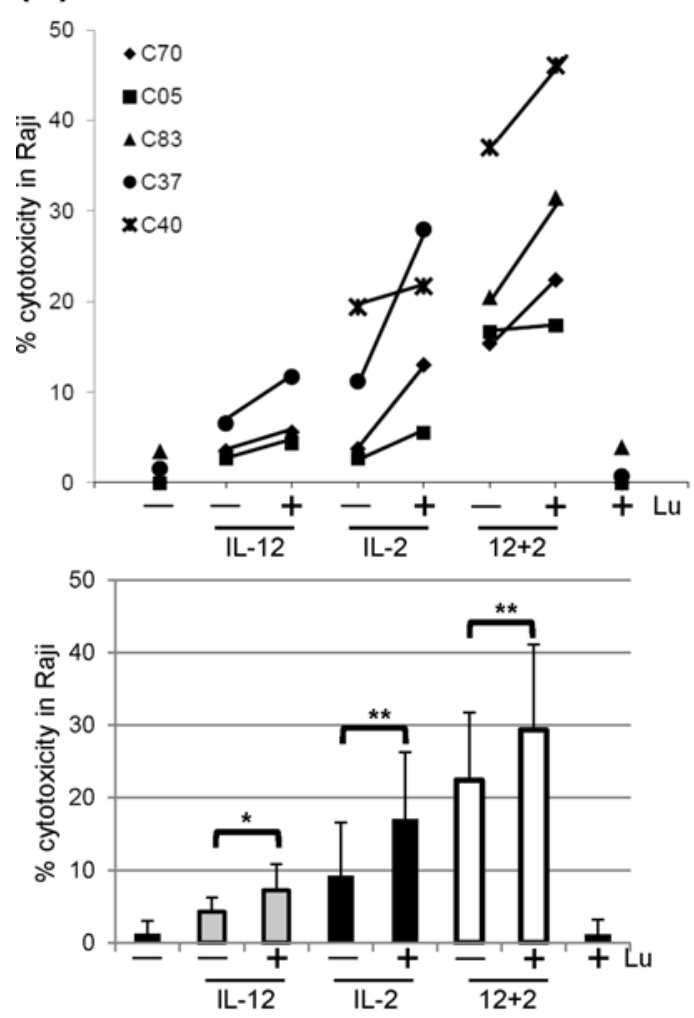

(B)

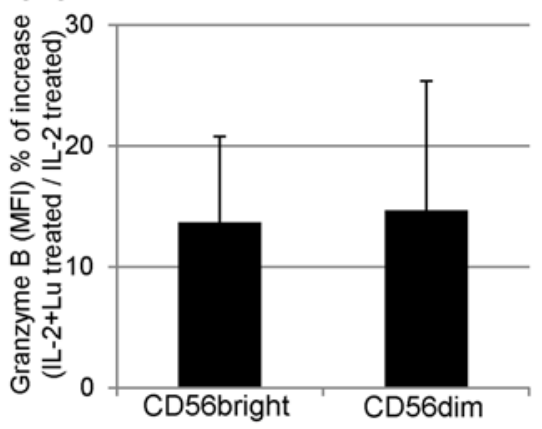

(C)

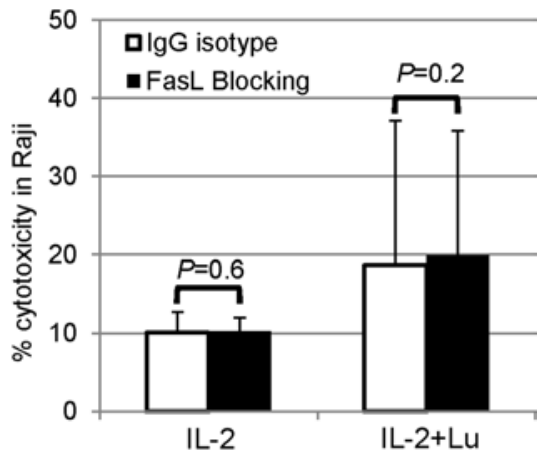

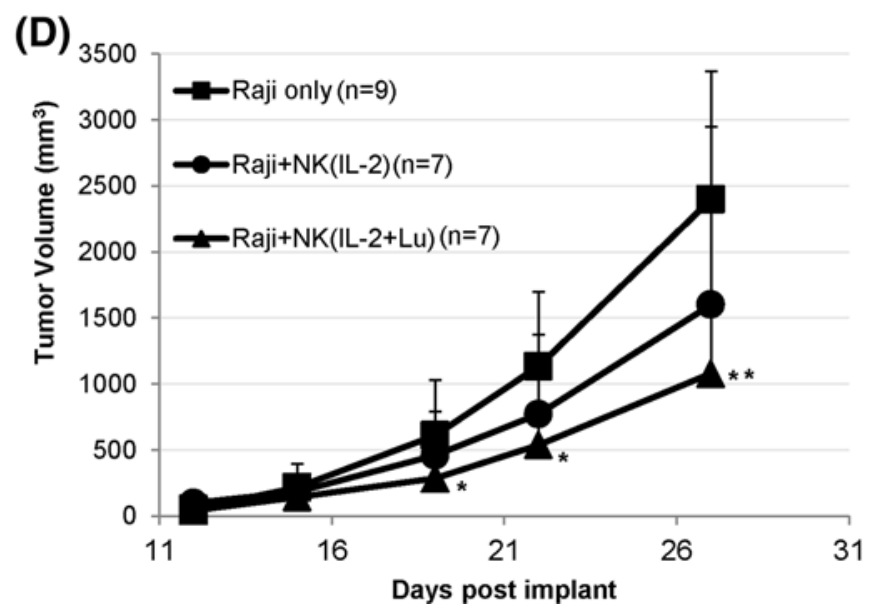

regulation in NK cells, and adding lunasin had no effect on levels of $\mathrm{H} 3 \mathrm{~K} 9 \mathrm{me} 3$ bound to these loci.

\section{STAT4 activation in lunasin-cultured NK cells}

STAT4 is required for IL-12-induced IFN $\gamma$ production by $\mathrm{T}$ and NK cells [20,39,40], and its activation is involved in H3 hyperacetylation at Ifng locus [41]. In this study, we observed activation of STAT4 in human NK cells following IL-2 stimulation, albeit stronger phospho-STAT4 was induced by IL-12 (Fig. 6d). The levels of pSTAT4 were higher in the cytokine-cultured NK cells containing lunasin
(Fig. 6d), suggesting that adding lunasin to cytokine-cultured NK cells enhanced STAT4 activation, which may also contribute to induction of IFNG by NK cells.

\section{Discussion}

Lunasin was first described for its chemopreventive properties that have been demonstrated in cell cultures and mice models [23]. In this study, we have found that lunasin exerts synergistic effects with cytokine IL-12 or IL-2 on modulating expression of a number of genes in NK cells. This 
4Fig. 4 Effects of lunasin on NK cell-mediated cytotoxicity against human B lymphoma Raji cell line. a NK-mediated cytotoxicity in vitro. Freshly isolated human NK cells from PBMCs of normal controls using negative selection (Miltenyi Biotec) were stimulated with medium only (-), single or both cytokines (IL-12 and IL-2) without $(-)$ or with $(+)$ lunasin $(20 \mu \mathrm{M})$, or lunasin alone for 1 day. Cytokines were used at suboptimum concentrations of $1 \mathrm{ng} / \mathrm{ml}$ for IL-12 and $10 \mathrm{U} / \mathrm{ml}$ for IL-2. The in vitro cytotoxicity was performed using lactate dehydrogenase (LDH)-releasing assay with the CytoTox 96 Non-Radioactive Cytotoxicity Assay Kit (Promega, Madison, WI). The effectors were co-cultured with target cells at ratio of 10:1 for $4 \mathrm{~h}$ at $37{ }^{\circ} \mathrm{C}$ in a $5 \% \mathrm{CO}_{2}$ incubator. The percentage of cytotoxicity was calculated according to the manufacturer's instructions. Each symbol represents an individual donor, and the percentage of cytotoxicity from each donor ( $n=5, \mathrm{C} 70, \mathrm{C} 05, \mathrm{C} 83, \mathrm{C} 37$, and C40) following various treatments is depicted in the upper panel of $\mathbf{a}$. The averaged percentage of cytotoxicity from 3 to 4 donors at each treatment is presented as mean $\pm \mathrm{SD}$ in the lower panel of $\mathbf{a}$. A mixed model including 6 levels of treatments was developed to analyze the data with within-subject treatments, and the pairwise comparisons among the treatments were performed to determine the $P$ values. $* P \leq 0.05$; $* * P \leq 0.01$. b Intracellular granzyme B staining from activated NK cells. Purified NK cells as in a were stimulated with suboptimum concentration of IL-2 $(10 \mathrm{U} / \mathrm{ml})$ alone or with lunasin $(20 \mu \mathrm{M})$ for 1 day followed by intracellular staining for granzyme B. The level of granzyme B expression was analyzed from CD56 bright and CD56 dim NK populations, and the geometric mean fluorescent intensity (MFI) was obtained using flow cytometry. The MFI of bright and dim populations treated with IL-2+ lunasin was compared to IL-2, and the percentage of increase in granzyme $\mathrm{B}$ expression is presented as Mean \pm SD averaged from 3 controls (b). c FasL-mediated killing by activated NK cells. Purified NK cells were stimulated as in $\mathbf{b}$ for 1 day followed by incubation with blocking antibody against FasL (filled bar) or IgG isotype control (open bar) for $2 \mathrm{~h}$. FasL-mediated killing by activated NK cells was determined using the in vitro cytotoxicity assay as in a. The percentage of cytotoxicity against Raji cells is presented as mean \pm SD averaged from 2 controls. d NKmediated cytotoxicity in a human Raji lymphoma xenograft model. $\mathrm{NOD} / \mathrm{SCID} / \mathrm{gc}^{\text {null }}$ (NSG) mice at 2 months old were injected subcutaneously on day 1 with $0.5 \times 10^{6}$ Raji cells in $0.1 \mathrm{ml}$ PBS mixed with $0.1 \mathrm{ml}$ Matrigel (BD Biosciences, San Jose, CA). NK cells were isolated from the leucopack of donors and treated with IL-2 (10 U/ $\mathrm{ml})$ or IL-2+ lunasin (lu, $20 \mathrm{uM}$ ) for 1 day. On day 2, these treated NK cells were washed and injected into the tumor site $\left(2.5 \times 10^{6} \mathrm{NK}\right.$ cells/mouse). Tumor growth was monitored, and the volumes were measured using standard manual calipers. Tumor volume $\left(\mathrm{mm}^{3}\right)$ is presented as mean \pm SD from 9 mice in the control group of Raji (no NK), and from 7 mice in the groups of Raji + NK (IL-2), and Raji + NK (IL-2+ lunasin). A mixed model with repeated measure to the data was developed using PROC MIXED in SAS program followed by pairwise comparison test of the mean differences among treatments by different days. ${ }^{*} P \leq 0.05$; ${ }^{*} P \leq 0.01$; relative to the control group of Raji (no NK)

synergism results in strong NK activation with enhanced cytotoxicity, which is associated with higher levels of IFN $\gamma$ and granzyme B expressed by both CD56 bright and dim populations. Adding lunasin to cytokine cocktails with both IL-12 and IL-2 was capable of rescuing the production of IFN $\gamma$ by NK cells from post-transplant lymphoma patients (Fig. 3), suggesting its potential application as an alternative strategy to improve the clinical outcomes by circumventing chemotherapy-induced immune dysfunction. Taken together, our results demonstrate that the combination of lunasin and selected cytokine (designated as lunakine) is superior to cytokine alone for harnessing NK-mediated anti-tumor functions.

In addition to cytokine stimulation, NK cells can be activated by engagement of co-stimulatory molecules through direct contact with other innate immune cells [42]. Interaction between activated $\gamma \delta \mathrm{T}$ and NK cells increases the cytotoxicity of NK cells via the CD137 engagement [43]. Thus, there is a possibility that $\gamma \delta \mathrm{T}$ or other innate immune cells remaining in the NK cultures following negative selection (97\% purity) may respond to treatment, which in turn activate NK cytotoxicity. Future studies will need to define cell types that can respond to lunasin-based treatment, as well as target genes that are regulated by such treatment. Our results suggest that enhanced cytotoxicity of NK cells following combination treatment with lunasin and cytokine is at least in part due to up-regulation of granzyme B that involves in the granule exocytosis pathway.

Using the Raji B lymphoma xenograft model, we showed that lunakine-treated NK cells could be used in cellular therapy following adoptive transfer (Fig. 4d). However, lunasin did not increase the number of NK cells cultured in cytokines (data not shown), suggesting its limited effect on survival or expansion of NK cells in cellular therapy. Nonetheless, we verified lunasin's in vivo effect on IFN $\gamma$ production and NK activation from mice following short-term treatment with IL-2 and lunasin (Fig. 5a-c). The suppressive effect following the long-term treatment (Fig. 5d, e) was not likely caused by the reduced number of NK cells systemically as these mice exhibited similar percentage of NK cells and total spleen cellularity (data not shown). Although the 8-week treatment used in our study is not a current practice, this result raises precautions in the future use of lunasin peptide, in which immune suppression is induced following immune activation in order to maintain homeostasis and avoid the unwanted immune responses. It will be imperative to optimize the doses of each agent and duration of treatment and to evaluate the bioavailability, biodistribution, and pharmacokinetic (PK) profile for lunasin in order to fully realize its clinical potential.

The synergistic effects of lunasin with selected cytokine such as IL-12 are in part due to reducing the levels of acetyl-H3 (Fig. 6b, lower panel), which further suppresses the expression of TGFB1 (Fig. 1i, upper panel). However, acetyl-H3 is associated with IFNG locus to a greater degree in NK cells treated with IL-12 plus lunasin than those treated with IL-12 only (Fig. 6b, upper panel). If the role of lunasin is solely dependent on inhibiting acetylation of histone, how can lunasin coordinately up- and down-regulate expression of different gene loci? One possibility is that lunasin can bind not only deacetylated but also acetylated histone proteins depending upon the preconditioned 


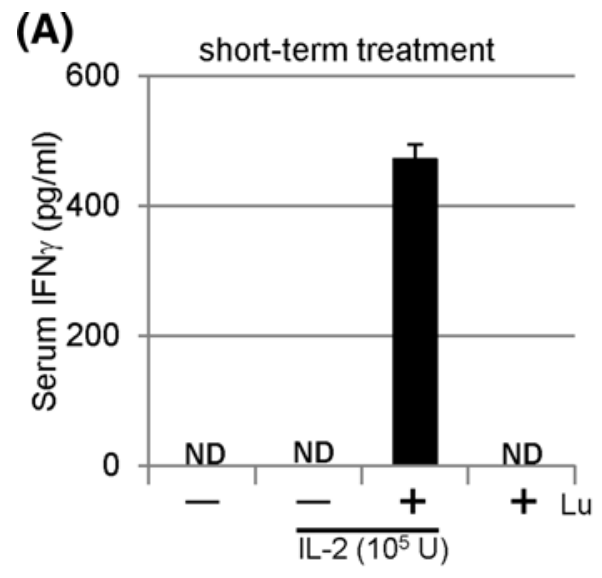

(B)
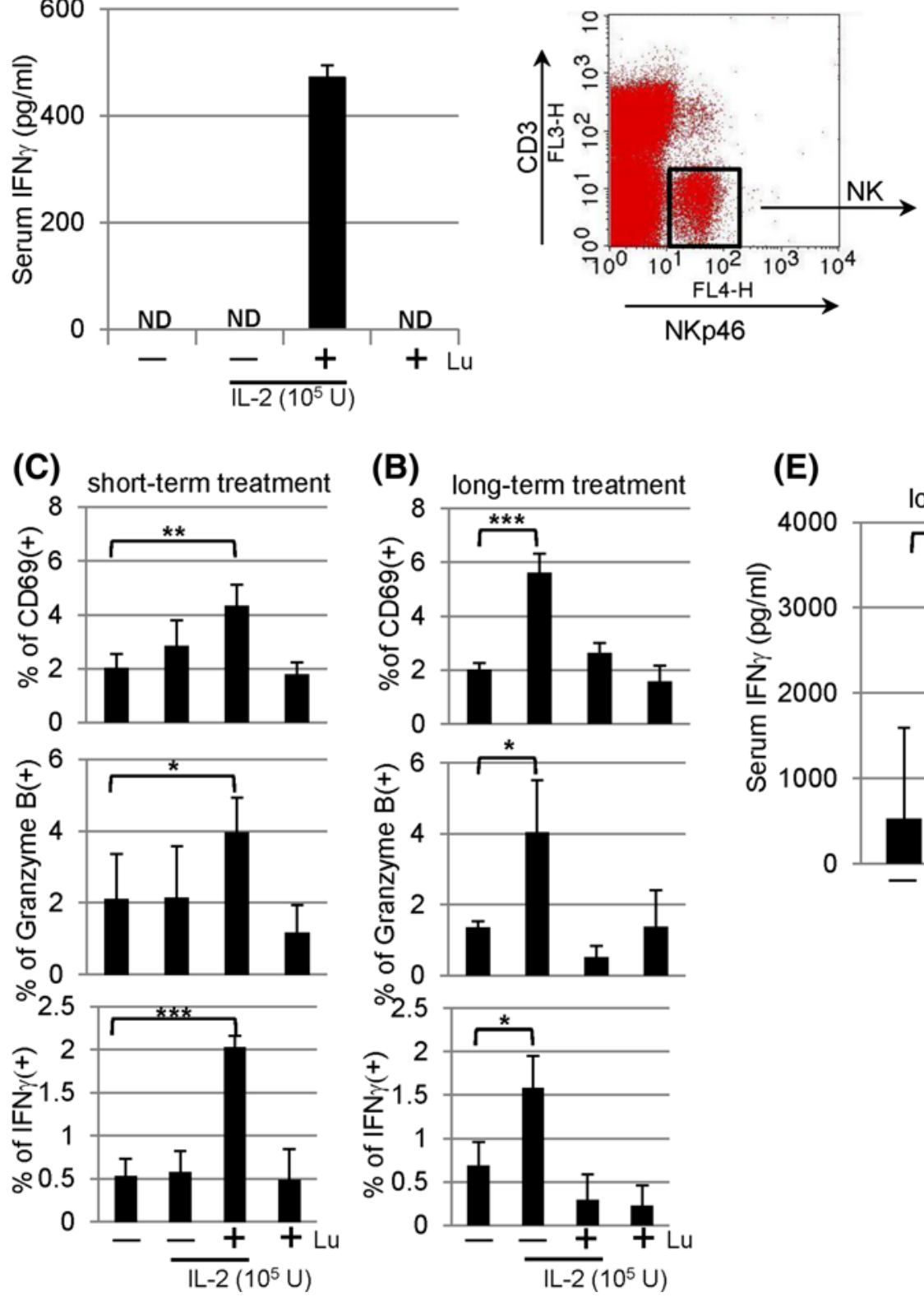

(B)
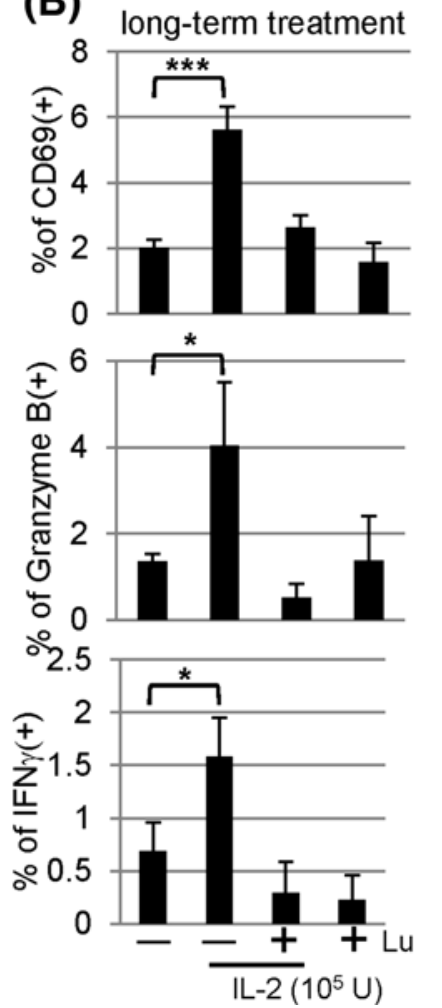

(E)

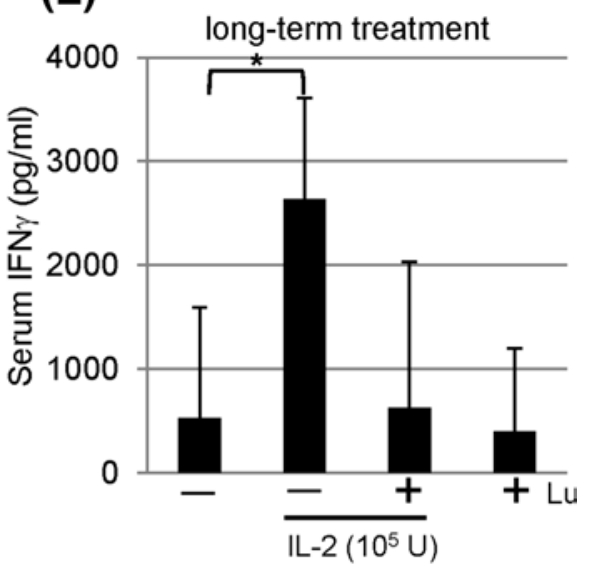

Fig. 5 In vivo effects of lunasin. a Lunasin enhances the secretion of IFN $\gamma$ in the serum. BALB/c mice received single intraperitoneal (IP) injection with PBS (-), IL-2 $\left(1 \times 10^{5} \mathrm{U} /\right.$ mouse $)$ without (-) or with $(+)$ lunasin $(0.4 \mathrm{mg} / \mathrm{kg}$ body weight), or lunasin alone as indicated. Mice were killed $18 \mathrm{~h}$ following injection, and blood samples were collected by cardiac puncture. The serum levels of IFN $\gamma$ were analyzed using ELISA. Data are presented as mean \pm SD from 3 mice per group. ND, not detectable. b, $\mathbf{c}$ NK activation in vivo following short-term treatment. BALB/c mice received single daily IP injection for 3 consecutive days as indicated. The following day mice were killed, and spleens were collected for analysis of NK activation using flow cytometry. NK cells gated on CD3- NKp46+ populations (b) were analyzed for surface expression of activation marker CD69 (c, upper panel) and intracellular staining for granzyme B (c, middle panel). The production of IFN $\gamma$ was analyzed from splenocytes that were incubated with GolgiPlug (Brefeldin A) for $4 \mathrm{~h}$ in vitro, and NK populations gated in $\mathbf{b}$ were analyzed for intracellular IFN $\gamma$ expression using flow cytometry (c, bottom panel). Data are presented as mean \pm SD averaged from 5 mice per group. d-e NK activation in vivo following long-term treatment. BALB/c mice received single daily IP injection for 5 consecutive days per week for a total of 8 weeks as indicated. Three days after the last injection, mice were killed, and spleens were collected for analysis of NK activation (d) using the same parameters as described in c. Blood samples were collected for analysis of serum IFN $\gamma$ using ELISA (e). Data are presented as mean $\pm \mathrm{SD}$ averaged from 5 mice per group. ${ }^{*} P \leq 0.05$; $* * P \leq 0.01 ; * * P \leq 0.001$ 
Fig. 6 Mechanisms of synergistic effects mediated by lunasin. a The RGD motif and poly-D tails are not required for the synergistic effects of lunasin on IFN $\gamma$ production by NK cells. Freshly isolated human NK cells (described in Fig. 1f) were stimulated with medium only $(-)$, IL-12 $(10 \mathrm{ng} / \mathrm{ml})$ without $(-)$ or with $(+)$ the full-length lunasin (Lu), mutant peptide (Mt) lacking the RGD motif and poly-D tail, or negative control (NC) peptide with scrambled amino acids as well as peptides only as indicated. The concentrations of the peptides used were $20 \mu \mathrm{M}$. One day following stimulation, the production of IFN $\gamma$ in the supernatants was determined using ELISA. Data are presented as mean \pm SD averaged from 2 different normal controls. b, c Chromatin remodeling at the loci of target genes. Freshly isolated human NK cells (described in Fig. 1f) were stimulated with medium only $(-)$, IL-12 $(10 \mathrm{ng} / \mathrm{ml})$ without $(-)$ or with $(+)$ lunasin $(20 \mu \mathrm{M})$, or lunasin alone. Following 1 day of stimulation, cells were subjected to the ChIP assay. Chromatin DNA fragments were immunoprecipitated with antibodies against acetyl-histone $\mathrm{H} 3(\mathrm{AcH} 3)$ (b) and histone $\mathrm{H} 3$ trimethyl Lys9 (H3K9me3) (c) along with non-immune rabbit serum (filled bars) (Millipore, Billerica, MA), individually. The relative degree of histone modification of IFNG and TGFBI loci was compared by qPCR using ChIP qPCR Primer Assay for human IFNG $(+1 \mathrm{~kb})$ and TGFB1 $(+1 \mathrm{~kb})$, respectively (SABioscience Qiagen, Valencia, CA). For calculation of ChIP results, the amount of immunoprecipitated DNA is normalized to the input chromatin in each reaction as a percentage of input (\% input). Data are shown as mean percentage of input $\pm \mathrm{SD}$ averaged from 3 controls. $* P \leq 0.05$. d STAT4 activation in lunasin-cultured NK cells. Freshly isolated human NK cells from PBMCs of normal controls (described in Fig. 1f) were stimulated with single cytokine IL-2 (10 U/ml) or IL-12 $(1 \mathrm{ng} / \mathrm{ml})$, or both cytokines in the absence $(-)$ and presence $(+)$ of lunasin $(20 \mu \mathrm{M})$ as well as medium and lunasin only. Activation of STAT4 was determined using Western blot of total protein extracts from cultured NK cells following $22 \mathrm{~h}$ of stimulation. Ratios of phospho-STAT4 to total STAT4 (pSTAT4/total STAT4) were determined from the arbitrary units of densitometry using the NIH ImageJ program as indicated. An anti- $\beta$-actin monoclonal (SC-47778) antibody (Santa Cruz Biotechnology, Santa Cruz, CA) was used for the loading control. Results shown are representative from 2 different normal controls with similar profiles

chromatin structure created by the selected cytokine such as IL-12. To identify histones that can physically interact with lunasin, we screened over 384 unique histone modifications using histone peptide assays (Active Motif, Carlsbad, CA). Indeed, lunasin is capable of binding to deacetylated $\mathrm{H} 3$ as well as $\mathrm{H} 3$ modifications that are associated with both gene activation and repression (data not shown). It has been shown that the level of acetyl-H3 is augmented following stimulation with IL-12, which contributes to induction of IFNG by NK cells [44]. We thus speculate that lunasin binds to the histone mark (acetyl-H3) created by initial cytokine exposure such as IL-12 [44], and this binding protects the target gene loci from changing its epigenetic state, and results in maintaining and stabilizing a nucleosome structure favorable for promoting transcription of target genes.

The molecular mechanisms mediated by lunasin require further investigation. Nonetheless, our results suggest that lunasin likely acts as an epigenetic modulator, which

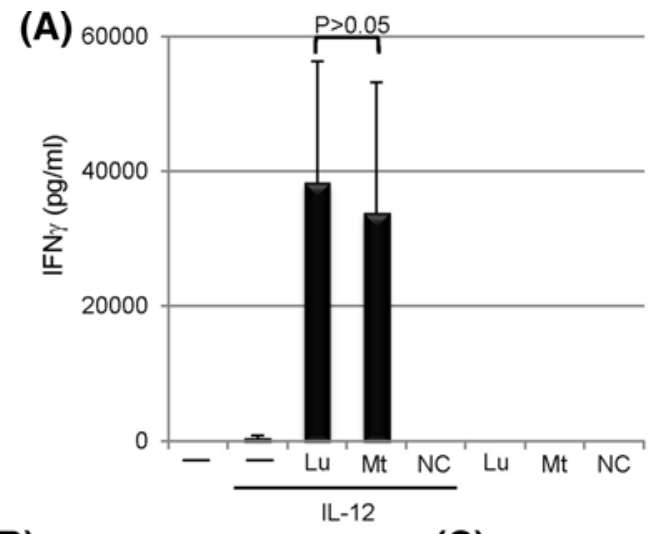

(B)
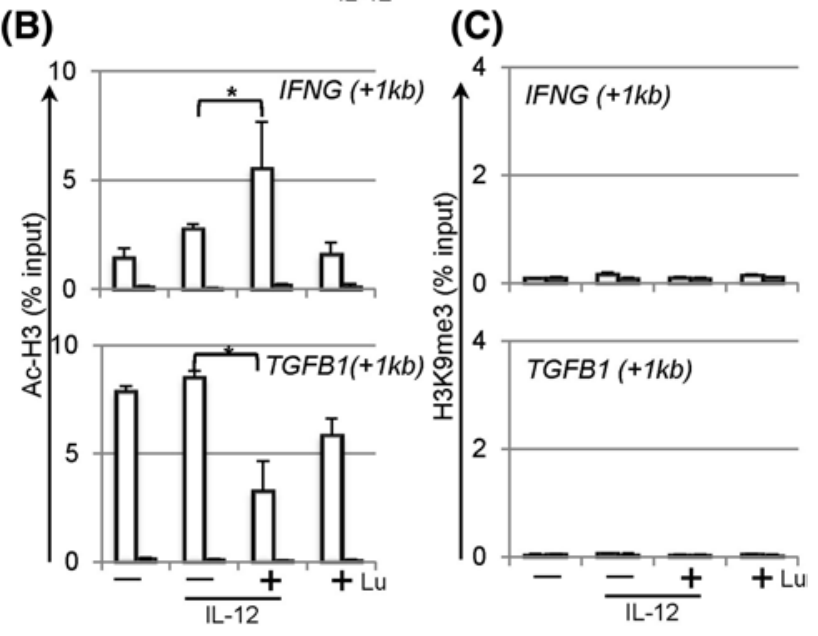

(D)
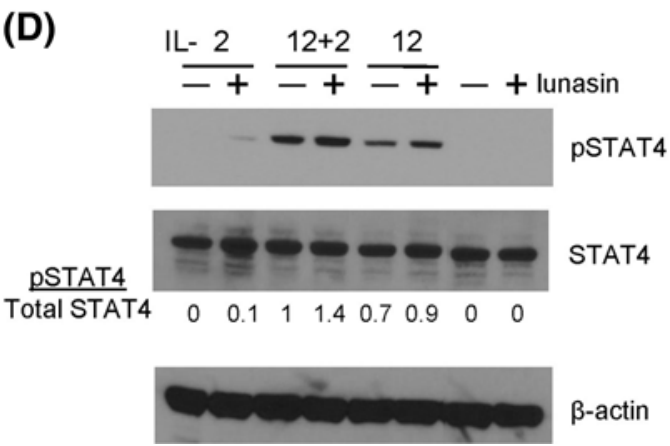

synergistically works with cytokines on regulating expression of susceptible genes in NK cells. Our discovery for the novel property of lunasin represents a different class of immune modulating agent that may augment the therapeutic responses by cytokine-based immunotherapy.

Acknowledgments This work was supported in part by American Cancer Society IRG (Hua-Chen Chang, Shivani Srivastava), Walther Scholar Grant (Shivani Srivastava) from the Indiana University Simon Cancer Center (P30 CA82709), and National Institutes of Health Grant RO1 CA118118 (Michael J. Robertson). The authors thank the nursing staff in the Indiana CTSI Clinical Research Center for collection of blood samples. We also thank Drs. Randy Brutkiewicz and Mark Kaplan for their invaluable suggestions. 


\section{Conflict of interest None.}

Open Access This article is distributed under the terms of the Creative Commons Attribution License which permits any use, distribution, and reproduction in any medium, provided the original author(s) and the source are credited.

\section{References}

1. Smyth MJ, Cretney E, Kershaw MH, Hayakawa Y (2004) Cytokines in cancer immunity and immunotherapy. Immunol Rev 202:275-293

2. Steimle V, Siegrist CA, Mottet A, Lisowska-Grospierre B, Mach B (1994) Regulation of MHC class II expression by interferongamma mediated by the transactivator gene CIITA. Science 265(5168):106-109

3. Min W, Pober JS, Johnson DR (1996) Kinetically coordinated induction of TAP1 and HLA class I by IFN-gamma: the rapid induction of TAP1 by IFN-gamma is mediated by Stat 1 alpha. $\mathbf{J}$ Immunol 156(9):3174-3183

4. Wang SH, Mezosi E, Wolf JM, Cao Z, Utsugi S, Gauger PG, Doherty GM, Baker JR Jr (2004) IFNgamma sensitization to TRAIL-induced apoptosis in human thyroid carcinoma cells by upregulating Bak expression. Oncogene 23(4):928-935

5. Gajewski TF, Fitch FW (1988) Anti-proliferative effect of IFNgamma in immune regulation. I. IFN-gamma inhibits the proliferation of Th2 but not Th1 murine helper T lymphocyte clones. J Immunol 140(12):4245-4252

6. Scott P (1991) IFN-gamma modulates the early development of Th1 and Th2 responses in a murine model of cutaneous leishmaniasis. J Immunol 147(9):3149-3155

7. Schoenborn JR, Wilson CB (2007) Regulation of interferongamma during innate and adaptive immune responses. Adv Immunol 96:41-101

8. Dunn GP, Koebel CM, Schreiber RD (2006) Interferons, immunity and cancer immunoediting. Nat Rev Immunol 6(11):836-848

9. Robertson MJ, Ritz J (1996) Interleukin 12: basic biology and potential applications in cancer treatment. Oncologist $1(1 \&$ 2):88-97

10. Son YI, Dallal RM, Mailliard RB, Egawa S, Jonak ZL, Lotze MT (2001) Interleukin-18 (IL-18) synergizes with IL-2 to enhance cytotoxicity, interferon-gamma production, and expansion of natural killer cells. Cancer Res 61(3):884-888

11. Fehniger TA, Cooper MA, Caligiuri MA (2002) Interleukin-2 and interleukin-15: immunotherapy for cancer. Cytokine Growth Factor Rev 13(2):169-183

12. Strengell M, Matikainen S, Siren J, Lehtonen A, Foster D, Julkunen I, Sareneva T (2003) IL-21 in synergy with IL-15 or IL-18 enhances IFN-gamma production in human NK and T cells. J Immunol 170(11):5464-5469

13. Srivastava S, Salim N, Robertson MJ (2010) Interleukin-18: biology and role in the immunotherapy of cancer. Curr Med Chem 17 (29):3353-3357

14. Brunda MJ, Luistro L, Hendrzak JA, Fountoulakis M, Garotta G, Gately MK (1995) Role of interferon-gamma in mediating the antitumor efficacy of interleukin-12. J Immunother Emphasis Tumor Immunol 17(2):71-77

15. Di Carlo E, Comes A, Orengo AM, Rosso O, Meazza R, Musiani P, Colombo MP, Ferrini S (2004) IL-21 induces tumor rejection by specific CTL and IFN-gamma-dependent CXC chemokines in syngeneic mice. J Immunol 172(3):1540-1547

16. Nastala CL, Edington HD, McKinney TG, Tahara H, Nalesnik MA, Brunda MJ, Gately MK, Wolf SF, Schreiber RD, Storkus
WJ et al (1994) Recombinant IL-12 administration induces tumor regression in association with IFN-gamma production. J Immunol 153(4):1697-1706

17. Robertson MJ, Cameron C, Atkins MB, Gordon MS, Lotze MT, Sherman ML, Ritz J (1999) Immunological effects of interleukin 12 administered by bolus intravenous injection to patients with cancer. Clin Cancer Res 5(1):9-16

18. Robertson MJ, Pelloso D, Abonour R, Hromas RA, Nelson RP Jr, Wood L, Cornetta K (2002) Interleukin 12 immunotherapy after autologous stem cell transplantation for hematological malignancies. Clin Cancer Res 8(11):3383-3393

19. Robertson MJ, Chang HC, Pelloso D, Kaplan MH (2005) Impaired interferon-gamma production as a consequence of STAT4 deficiency after autologous hematopoietic stem cell transplantation for lymphoma. Blood 106(3):963-970

20. Chang HC, Han L, Goswami R, Nguyen ET, Pelloso D, Robertson MJ, Kaplan MH (2009) Impaired development of human Th1 cells in patients with deficient expression of STAT4. Blood 113(23):5887-5890

21. Lupov IP, Voiles L, Han L, Schwartz A, De La Rosa M, Oza K, Pelloso D, Sahu RP, Travers JB, Robertson MJ, Chang HC (2011) Acquired STAT4 deficiency as a consequence of cancer chemotherapy. Blood 118 (23):6097-6106

22. Odani S, Koide T, Ono T (1987) Amino acid sequence of a soybean (Glycine max) seed polypeptide having a poly(L-aspartic acid) structure. J Biol Chem 262(22):10502-10505

23. Galvez AF, Chen N, Macasieb J, de Lumen BO (2001) Chemopreventive property of a soybean peptide (lunasin) that binds to deacetylated histones and inhibits acetylation. Cancer Res 61(20):7473-7478

24. Tato CM, Martins GA, High FA, DiCioccio CB, Reiner SL, Hunter CA (2004) Cutting Edge: innate production of IFNgamma by NK cells is independent of epigenetic modification of the IFN-gamma promoter. J Immunol 173(3):1514-1517

25. Kayagaki N, Kawasaki A, Ebata T, Ohmoto H, Ikeda S, Inoue S, Yoshino K, Okumura K, Yagita H (1995) Metalloproteinase-mediated release of human Fas ligand. J Exp Med 182(6): 1777-1783

26. Chang HC, Zhang S, Thieu VT, Slee RB, Bruns HA, Laribee RN, Klemsz MJ, Kaplan MH (2005) PU.1 expression delineates heterogeneity in primary Th2 cells. Immunity 22(6):693-703

27. Chang HC, Han L, Jabeen R, Carotta S, Nutt SL, Kaplan MH (2009) PU.1 regulates TCR expression by modulating GATA-3 activity. J Immunol 183(8):4887-4894

28. Cooper MA, Fehniger TA, Turner SC, Chen KS, Ghaheri BA, Ghayur T, Carson WE, Caligiuri MA (2001) Human natural killer cells: a unique innate immunoregulatory role for the CD56(bright) subset. Blood 97(10):3146-3151

29. Caligiuri MA (2008) Human natural killer cells. Blood 112(3):461-469

30. Yu J, Wei M, Becknell B, Trotta R, Liu S, Boyd Z, Jaung MS, Blaser BW, Sun J, Benson DM Jr, Mao H, Yokohama A, Bhatt D, Shen L, Davuluri R, Weinstein M, Marcucci G, Caligiuri MA (2006) Pro- and antiinflammatory cytokine signaling: reciprocal antagonism regulates interferon-gamma production by human natural killer cells. Immunity 24(5):575-590

31. Miller JS, Soignier Y, Panoskaltsis-Mortari A, McNearney SA, Yun GH, Fautsch SK, McKenna D, Le C, Defor TE, Burns LJ, Orchard PJ, Blazar BR, Wagner JE, Slungaard A, Weisdorf DJ, Okazaki IJ, McGlave PB (2005) Successful adoptive transfer and in vivo expansion of human haploidentical NK cells in patients with cancer. Blood 105(8):3051-3057

32. Srivastava S, Lundqvist A, Childs RW (2008) Natural killer cell immunotherapy for cancer: a new hope. Cytotherapy 10(8):775-783 
33. Ljunggren HG, Malmberg KJ (2007) Prospects for the use of NK cells in immunotherapy of human cancer. Nat Rev Immunol 7(5):329-339

34. Carson WE, Dierksheide JE, Jabbour S, Anghelina M, Bouchard $\mathrm{P}, \mathrm{Ku}$ G, Yu H, Baumann H, Shah MH, Cooper MA, Durbin J, Caligiuri MA (2000) Coadministration of interleukin-18 and interleukin-12 induces a fatal inflammatory response in mice: critical role of natural killer cell interferon-gamma production and STAT-mediated signal transduction. Blood 96(4):1465-1473

35. Ruoslahti E, Pierschbacher MD (1986) Arg-Gly-Asp: a versatile cell recognition signal. Cell 44(4):517-518

36. Galvez AF, de Lumen BO (1999) A soybean cDNA encoding a chromatin-binding peptide inhibits mitosis of mammalian cells. Nat Biotechnol 17(5):495-500

37. Jaenisch R, Bird A (2003) Epigenetic regulation of gene expression: how the genome integrates intrinsic and environmental signals. Nat Genet 33(Suppl):245-254

38. Berger SL (2007) The complex language of chromatin regulation during transcription. Nature 447(7143):407-412

39. Kaplan MH, Sun YL, Hoey T, Grusby MJ (1996) Impaired IL-12 responses and enhanced development of Th2 cells in Stat4-deficient mice. Nature 382(6587):174-177
40. Thierfelder WE, van Deursen JM, Yamamoto K, Tripp RA, Sarawar SR, Carson RT, Sangster MY, Vignali DA, Doherty PC, Grosveld GC, Ihle JN (1996) Requirement for Stat4 in interleukin-12-mediated responses of natural killer and T cells. Nature 382(6587):171-174

41. O’Sullivan A, Chang HC, Yu Q, Kaplan MH (2004) STAT4 is required for interleukin-12-induced chromatin remodeling of the CD25 locus. J Biol Chem 279(8):7339-7345

42. Fernandez NC, Lozier A, Flament C, Ricciardi-Castagnoli P, Bellet D, Suter M, Perricaudet M, Tursz T, Maraskovsky E, Zitvogel L (1999) Dendritic cells directly trigger NK cell functions: crosstalk relevant in innate anti-tumor immune responses in vivo. Nat Med 5(4):405-411

43. Maniar A, Zhang X, Lin W, Gastman BR, Pauza CD, Strome SE, Chapoval AI (2010) Human gammadelta T lymphocytes induce robust NK cell-mediated antitumor cytotoxicity through CD137 engagement. Blood 116(10):1726-1733

44. Bream JH, Hodge DL, Gonsky R, Spolski R, Leonard WJ, Krebs S, Targan S, Morinobu A, O'Shea JJ, Young HA (2004) A distal region in the interferon-gamma gene is a site of epigenetic remodeling and transcriptional regulation by interleukin-2. J Biol Chem 279(39):41249-41257 